\title{
Notes on the Bionomics of the Pink Stem Borer Sesamia inferens Walker (Lepidoptera: Noctuidae): An Upcoming Pest of Wheat in India
}

\author{
BEANT SINGH ${ }^{1 *}$ and J. S. KULAR ${ }^{2}$ \\ ${ }^{1}$ Department of Plant Breeding and Genetics, ${ }^{2}$ Department of Entomology, \\ Punjab Agricultural University, Ludhiana-141004, Punjab, India
}

(Received: 9 March 2015; accepted: 26 March 2015)

\begin{abstract}
Wheat cultivation is of great significance in North-western plains of India and the crop was hitherto considered as almost free from serious insect attack. Recently, Pink stem borer (PSB), Sesamia inferens Walker (Lepidoptera: Noctuidae) has emerged as a new pest and is likely to pose serious threat to the successful cultivation of wheat in the North-western plains of India under largely adopted rice-wheat cropping system. Because of the paucity of data on the developmental biology of PSB on wheat crop regarding this emerging problem of insect damage, studies were initiated on biology of PSB under field as well as screenhouse conditions during seasons of 2010-2011 and 2011-2012. This is the first report on biology of PSB on wheat which indicated that the pest was able to survive well/build up populations on wheat and able to complete its life cycle. It laid eggs either at the base of wheat plant near to soil level or on soil-surface or in the left over stubble of rice plants. Eggs hatched within $7.40 \pm 0.08$ days and the mean larval duration was $68.52 \pm 1.55$ days. In the course of development, it passed through 8 larval instars and pupation took place near or within the left over rice stubble. Pupal period was $36.05 \pm 0.36$ days in male while $37.78 \pm 0.17$ days in female. The survival of adult moths was $5.31 \pm 0.26$ days in male while $6.61 \pm 0.26$ days in female. The mean fecundity was $118.38 \pm 11.93$ eggs and 89.15 per cent of eggs hatched. The total life cycle took $116.92 \pm 2.17$ and $119.95 \pm 2.05$ days in males and females, respectively.
\end{abstract}

Keywords: bionomics, Sesamia inferens, upcoming pest, wheat, new host plant.

Wheat (Triticum aestivum L.) is an important cereal crop and serves as staple food in many low- and middle-income countries. The decline in its use is expected in the next decade due to shift towards diversified diet (Trostle and Seeley, 2013). However, overall global demand for wheat will increase in developing countries (Lisa et al., 2000). Hitherto, wheat crop remained free from serious insect pest problems. However, recently pink stem borer (PSB) Sesamia inferens Walker (Lepidoptera: Noctuidae) has been detected damaging wheat crop in pockets in India (Dhaliwal et al., 2010).

PSB is an insect commonly recorded in pest form on rice crop in Asian region such as China (Liu, 1990), Philippines (Pathak and Khan, 1994), Taiwan (Huang et al., 2008) Sri lanka (Rajendra, 1976) and India (Pathak, 1975), etc. PSB not only attacks rice crop but also other cereals like wheat (Lina et al., 2012), maize (Sekhar et al., 2009) and sug-

* Corresponding author; e-mail: beant19@pau.edu 
arcane (Rajendra, 1976), etc. Infact this is a polyphagous pest recorded on several weeds (Khan et al., 1991). North-Western plains of India showed significant damage in wheat crop under rice-wheat cropping system (Anonymous, 2008). The PSB inflicts 3-5\% damage in Punjab (Ram et al., 2011; Singh and Kular, 2012) and 5.7 to 11.1 per cent in Rajasthan (Singh, 1986). Insect causes 'dead hearts' at seedling stage and produce 'white ears' at earhead stage (Deol, 2002). With the continuous cultivation of rice-wheat system, the intensity of its attack is likely to increase further in future.

So far, several studies concerning the phenology, biology, genetic differentiation, and control of S. inferens in rice crop have been reported in detail (Patel and Verma, 1980; Dale, 1994; Karim and Riazuddin, 1999). However, there is a great lack of experimental data focusing on different developmental periods or adult longevity of $S$. inferens in wheat crop. To overcome this paucity of data, the current studies were conducted to understand the pest biology in this crop in the existing rice-wheat production system. It was our goal to determine whether PSB was able to complete its life cycle on wheat crop and find out developmental times and survivorship of different growth stages in wheat crop. In addition, place of egg laying and pupation in field as well as laboratory conditions was also investigated. The knowledge of such laboratory and field data of PSB on wheat is important for determining seasonal occurrence of population and develop strategies for integrated pest management.

\section{Materials and Methods}

\section{Experimental site and material}

The studies were conducted at the Experimental area of the Department of Plant Breeding and Genetics, Punjab Agricultural University (PAU), Ludhiana (30 $55^{\prime} \mathrm{N}$ and 75 54' E, $247 \mathrm{~m}$ above the sea level) during 2010-2011 and 2011-2012. The present investigations were carried out on wheat variety PBW 550 variety under screen houses $(363 \times 109 \times 180 \mathrm{~cm})$ fitted with 30 mesh galvanized wire gauze. The split cages $($ Severin, 1931) were used to confine PSB on the potted wheat to study the biology of pest. The pots of size 20 and $25 \mathrm{~cm}$ diameter were used for raising the test plants and also for studying the various aspects of the biology of PSB on wheat crop. A small hole was made at the bottom of pots to drain excess irrigation water. The glass jars covered with muslin cloth were used to rear the larvae of PSB on the cut stem pieces of lower end wheat plants. To prevent the drying of the stem pieces, moistened cotton swab was placed at the base of the jars. For raising insect culture, 4-5 seeds of wheat variety PBW 550 were sown at weekly intervals in earthen pots having well tilled soil. About one week after germination, these were thinned out to five tillers per pot. These earthen pots were watered regularly and fertilizers were applied as per recommendations of PAU Package of Practices to keep the plants healthy (Anonymous, 2010). Forty to fifty days old plants were used for experimentation. 


\section{Environmental conditions}

The region has a sub-tropical climate with hot, wet summers and cool, dry winters. The data pertaining to environmental conditions viz. maximum temperature, minimum temperature, average temperature and relative humidity during 2010-2011 and 2011-2012 are presented in Fig. 1a, b.

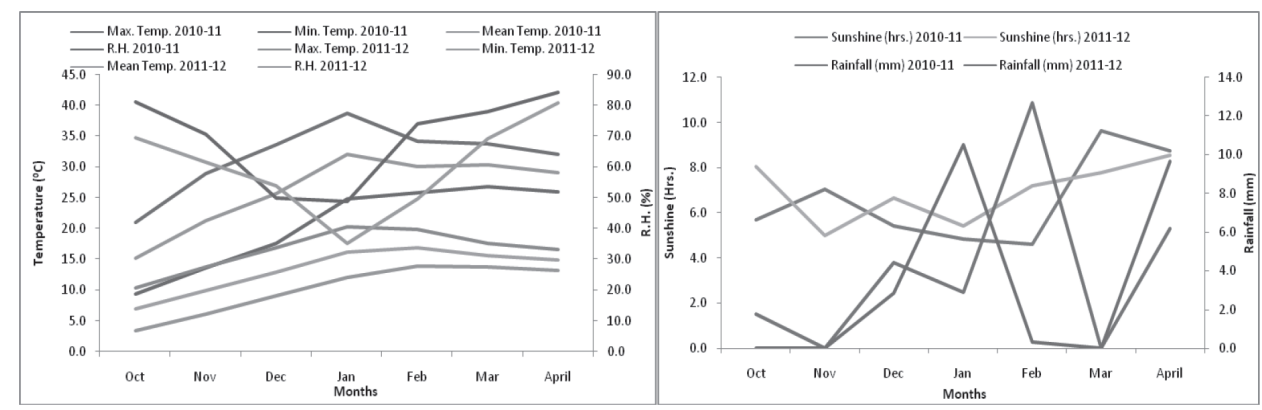

Fig. 1a, b. Different weather parameters during wheat growing seasons in 2010-2011 and 2011-2012

\section{Maintenance of insect culture}

The larvae and pupae of $S$. inferens were collected from different hosts, viz. rice, wheat, maize and sugarcane depending upon their availability. The collected larvae were reared by feeding them on cut pieces of fresh wheat/rice plants kept in the glass jars. Transverse cuts were given at the lower end of the stem pieces to facilitate the larval entry to the food. The mouth of the jar was covered with a piece of muslin cloth, tied securely with rubber bands. The cut pieces of wheat/rice stem were changed after every 2-3 days or as needed until the pupae were formed. The fresh pupae collected from the field as well as newly formed pupae from culture, were transferred to other battery glass jars having moist foam at the bottom and the open end of the jar was covered with a piece of muslin cloth and tied with rubber band. The moths emerging from the pupae were transferred to oviposition jars (Fig. 2) to obtain egg masses. Five pairs (5 male and 5 female) of newly emerged moths were released in an oviposition jar. The layer of sand was covered by a suitably cut circular piece of ordinary paper and then with wax paper to avoid direct contact of moth with moist sand. The inner side of the jar was lined with wax paper for obtaining egg masses. After the release of moths, the mouths of the jars were also covered with a piece of muslin cloth tied with rubber bands. As the insect is active during night, these jars were covered with black paper to mimic nocturnal conditions. These oviposition jars were opened seven days after release of the moths. The culture of larvae was also maintained on the potted wheat plants kept in the rearing cages as well as artificial diet. The adults emerged from the pupae were used to study the various aspects of biology: 


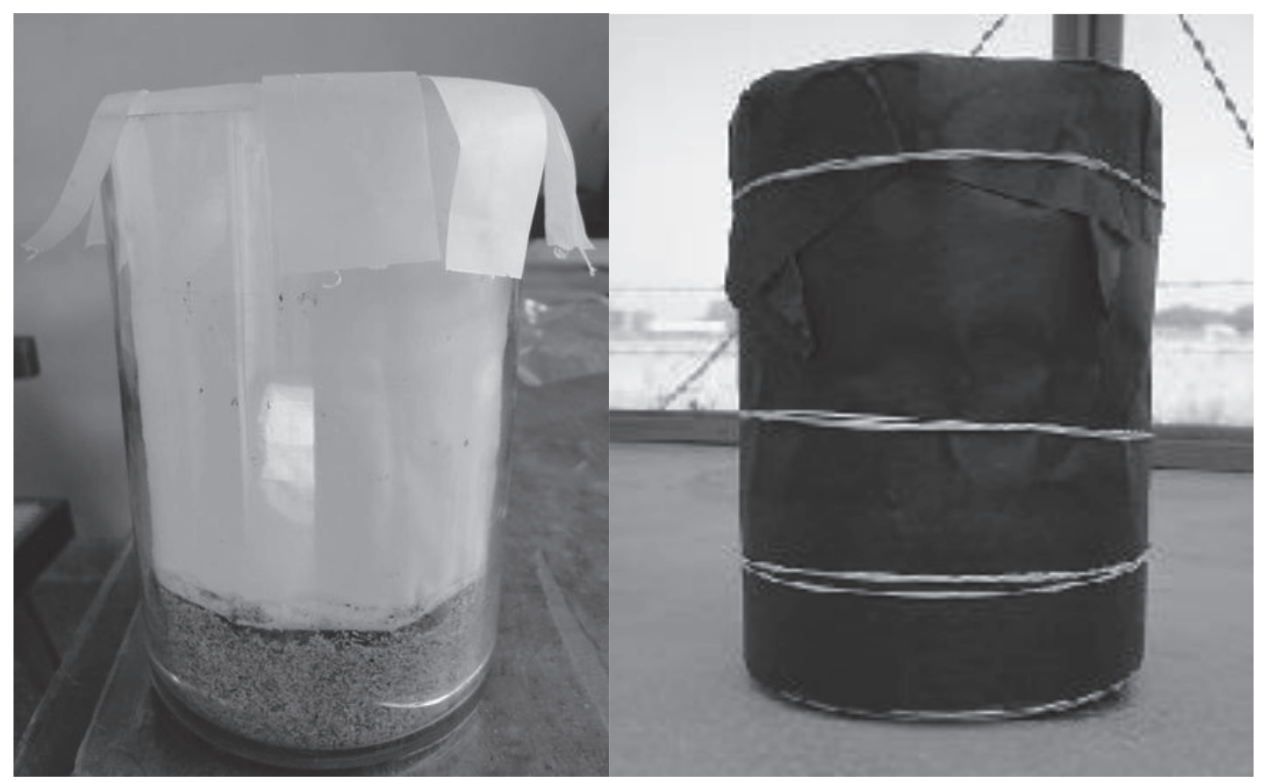

Fig. 2. Ovipositional and hatching jars used to study the biology of Sesamia inferens

\section{Egg stage}

The observations were made on colour, shape, time of observation, incubation period and site of oviposition w.r.to egg stage.

Time of oviposition:

The oviposition was recorded in glass jars during October, November and December for two years (2010-2011 and 2011-2012). A pair of 1-day-old adults was confined in each jar and eggs were counted after every two hours from 12.00 to $24.00 \mathrm{hr}$. The eggs were counted separately for five successive nights/until the death of females. In all, there were ten replicates. To obtain sufficient mated females, the method developed by Calatayud et al. (2007) was followed. One-day-old females were placed into glass jars with the onset of the evening and one day old males were introduced one hour later. The jars were wrapped from inside with wax paper to serve as oviposition substrate.

Incubation period:

To record incubation period, the wax papers containing eggs were taken out and cut into desired size of egg mass and placed in petri dishes provided with moist cotton swabs till the eggs reached black head stage. The numbers of eggs hatched were counted daily from 06:00 and 18:00 hr. 
Site of oviposition:

The site of oviposition was studied on wheat under natural and artificial conditions atmosphere in earthen pot covered with split cages. In natural conditions, wheat fields were monitored at fortnightly intervals for the presence of eggs of PSB throughout the season. The base of wheat seedling as well as left over stubble of rice plants and soil surface was also examined for the presence of eggs.

In artificial conditions, 1-day-old mated females were taken from the culture and were released on plants covered with split cage. In all, 10 pots were used to study the site of oviposition under artificial conditions. It was determined by carefully examining earthen pots daily. The same experiment was also repeated in earthen pots having stubble of rice plants.

\section{Larval stage}

The observations were made on colour, adult behaviour and larval duration w.r.to adult stage.

Larval duration:

Larval duration of first two instars was studied in plastic/straw pipes while third instar onward, it was studied in cut-pieces of wheat stem placed in glass jars. The cut pieces of wheat leaves were placed within the plastic pipes to serve as food for first two instars. Fresh leaves were added daily in these pipes and excreta of larvae were also cleaned regularly from these pipes. However, cut pieces of wheat stem (approx. $15 \mathrm{~cm}$ long) used to study $3-8^{\text {th }}$ and these were replaced after every $2-3$ days depending upon their conditions. The changes in larval instar were recorded daily by observing moulted skin (exuvae)/head capsules. The behaviour of different larval instars was also recorded.

\section{Pupal stage}

The observations were made on colour, pupal periods, and site of pupation w.r.to adult stage. The male and female pupae were differentiated on the basis of pupal size as well as genital aperture.

\section{Pupal duration:}

The time taken from pre-pupal period (larvae stopped feeding) to adult emergence was taken as pupal period. On pupation, the insects were transferred to glass jars having moist foam at the bottom and these were covered with a piece of muslin cloth and tied with rubber band to study pupal duration.

\section{Site of pupation:}

The site of pupation was studied naturally in wheat field as well as artificially in earthen pots covered with split cages having wheat seedling. The wheat fields were monitored for the presence of pupae of PSB at fortnightly intervals throughout the season. The site of pupation was observed in field by dissecting the wheat plants, by searching the soil and stubble of rice plants. The 10-15 wheat tillers were dissected on each date of observation. 
In artificial conditions, late larval instars, i.e. $7^{\text {th }}$ or $8^{\text {th }}$ were taken from the culture and were released on plants covered with split cages. In all, 10 pots were used to study the site of pupation. It was determined by carefully examining earthen pots on each alternating day after 10 days of their release. The same experiment was also repeated in earthen pots having wheat seedlings as well as stubble of rice plants.

\section{Adult stage}

The observations were made on colour, adult longevity, oviposition periods, fecundity and hatchability w.r.to adult stage.

Adult longevity and ovipositional periods:

The period from the day of emergence of a female to the day when it started laying eggs was taken as pre-oviposition period. It was recorded by releasing two pairs in the jars and observations were made after every 6 hours. The number of days for which a female continued to lay eggs was considered as the oviposition period and post-oviposition period was taken as the time interval between the termination of egg laying and death of females. The sum of pre-oviposition, oviposition period and post-oviposition period was calculated as adult longevity. The laboratory reared adults were sorted to record the sex-ratio i.e. number of male and female individuals.

Fecundity and hatchability:

Fecundity was studied in glass jars covered from inside with wax paper. Two pairs of newly emerged moths were transferred to oviposition jars for obtaining egg masses (Fig. 2). The total numbers of eggs were counted and fecundity was calculated. The hatchability was observed in petri plates. The wax paper containing eggs was taken out and cut into desired size of egg masses and placed in petri dishes provided with moist cotton till the eggs reached black head stage. Number of hatched eggs was counted to calculate per cent hatchability.

\section{Total life cycle}

The total life cycle of PSB was calculated by adding the duration of different developmental stages of insect, i.e. from egg to adult stage.

\section{Data analysis}

The developmental time of each growth stage was compared across temperature and relative humidity using one-way analysis of variance (ANOVA) and unplanned comparison of means were done using Tukey's HSD test $(\mathrm{p}=0.05)$ (Gomez and Gomez, 1984). However incubation period, hatching, fecundity was compared using two-way ANOVA with multiple observations per cell. To stabilize variance, pre-ovipositional, ovipositional period and fecundity data were square root transformed while hatching data were arcsine transformed. 


\section{Results and Discussion}

\section{Egg stage}

The freshly laid eggs of $S$. inferens were small, oval and greenish-creamy white in colour which became slightly pinkish and finally turned blackish grey near hatching. The unfertilized eggs remained creamy white and were shrunken in shape. Similar observations on description of PSB were observed by Rajendra (1976) on sugarcane and Dale (1994) on rice crop.

Time of oviposition:

The insect being nocturnal, egg laying was restricted to night or dusk hours. The peak ovipositional activity was observed 24 hours after mating which decreased subsequently (Fig. 3). Forty five per cent of the eggs were laid during the first night followed by 32 per cent on second night after mating. Egg laying was recorded up to the $5^{\text {th }}$ night after mating night. Oviposition was maximum in the month of October and minimum in December during both the years (2010 and 2011) (Figs 4 and 5). Within a day, egg laying was maximum between 18:00-20:00 hrs (51.6-68.5\%) followed by 20:00-22:00 hrs $(14.3-27.5 \%)$ in both years of study. The egg laying decreased drastically during 22:0024:00 hrs (1.1-7.9\%). In most of the noctuid stem borer species, oviposition occurs during evening and night hours (Pathak, 1975; Adler et al., 1991) and the present study also evidenced the nocturnal behaviour of $S$. inferens. The difference in light period seems to be the cause of variation in oviposition time in different months. Eizaguirre et al. (1994) and Fantinou et al. (1995) also reported that photoperiod was a major factor in growth and

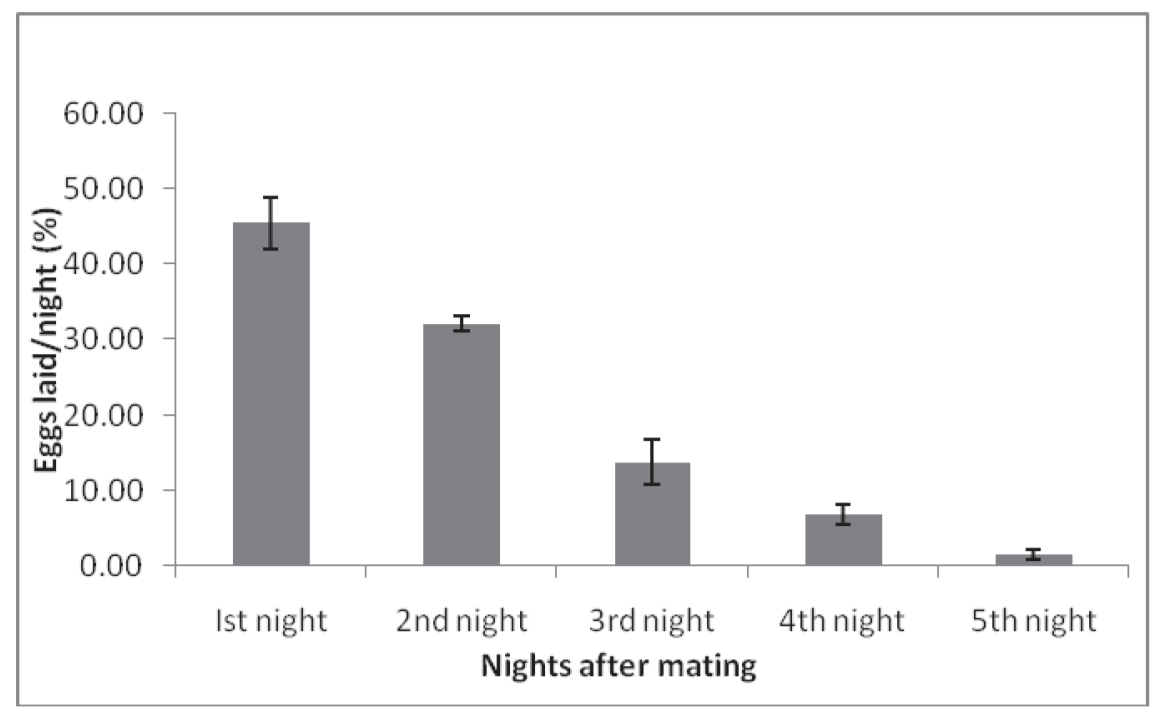

Fig. 3. Relative proporation of eggs laid by female during first five nights 


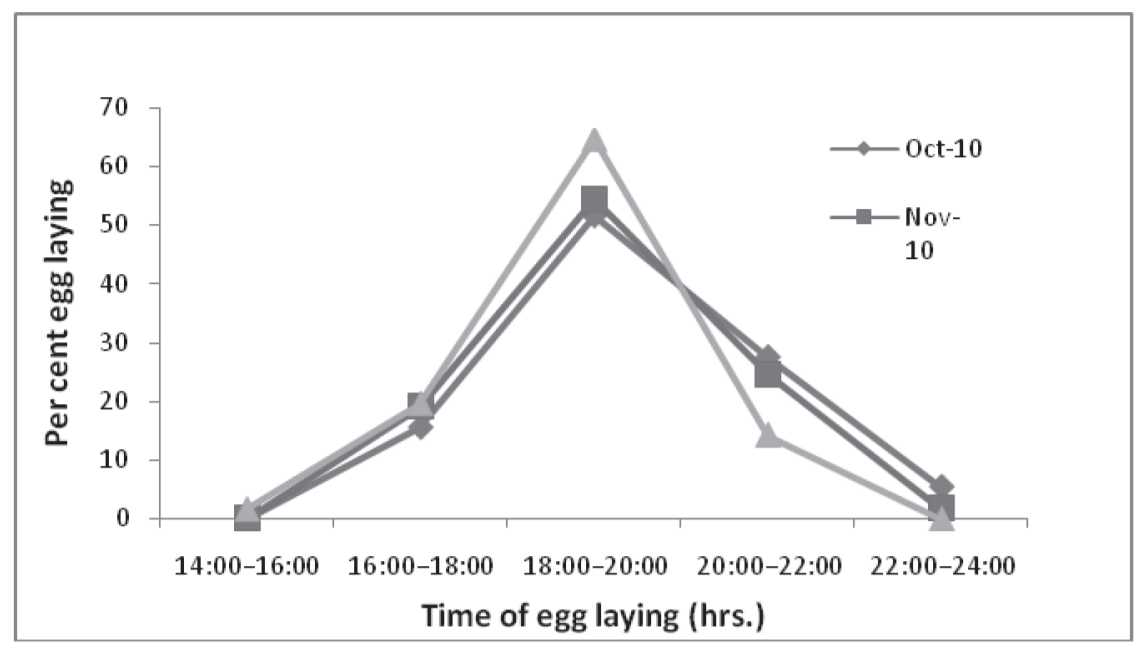

Fig. 4. Time of oviposition of S. inferens in different months during 2010

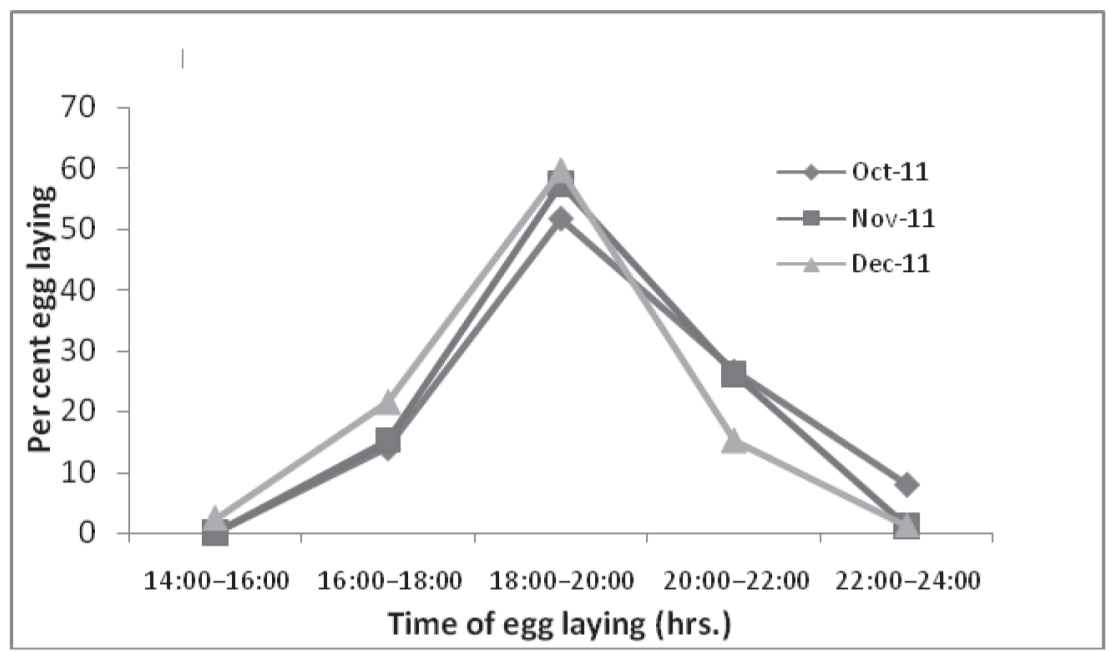

Fig. 5. Time of oviposition of S. inferens in different months during 2011

development of $S$. nonagrioides. Oviposition was reported to be suppressed when S. nonagrioides were exposed to long days (Fantinou et al., 2004).

Incubation period and hatching:

There was no difference $(\mathrm{p}>0.05 ; \mathrm{F}=0.21 ; \mathrm{df}=2,12)$ in incubation period during 2010-2011 (7.37 \pm 0.09 days) and 2011-2012 (7.42 \pm 0.06 days) (Table 1). However, it was significantly more in the months of December-January (7.56 \pm 0.05 days) as compared to October-November ( $7.25 \pm 0.06$ days) which was on a par with November-December (7.42 \pm 0.12 days). The duration of egg stage ranged between 6-11 days during 
Table 1

Incubation period of S. inferens in different months during 2010-2011 and 2011-2012 crop season

\begin{tabular}{|c|c|c|c|c|c|c|c|}
\hline \multirow{2}{*}{ Years } & \multicolumn{2}{|c|}{ Incubation period (days) } & \multicolumn{3}{|c|}{ Temperature } & \multirow{2}{*}{$\begin{array}{l}\text { Relative } \\
\text { humidity }\end{array}$} & \multirow{2}{*}{$\begin{array}{c}\text { Sunshine } \\
\text { hours }\end{array}$} \\
\hline & Range & Mean \pm S.E. & Max. & Min. & Mean & & \\
\hline $2010-2011$ & $6-13$ & $7.37 \pm 0.09 a$ & 23.2 & 9.0 & 16.1 & 72.8 & 5.7 \\
\hline 2011-2012 & $6-13$ & $7.42 \pm 0.06 \mathrm{ba}$ & 24.7 & 11.1 & 17.4 & 71.2 & 4.5 \\
\hline \multicolumn{8}{|l|}{ Months } \\
\hline Oct-Nov & $6-11$ & $7.25 \pm 0.06 b$ & 29.3 & 13.8 & 21.6 & 65.5 & 6.9 \\
\hline Nov-Dec & $6-13$ & $7.42 \pm 0.12 \mathrm{ab}$ & 24.8 & 9.8 & 17.3 & 71.3 & 5.5 \\
\hline Dec-Jan & $6-13$ & $7.56 \pm 0.05 a$ & 17.7 & 6.6 & 11.5 & 79.2 & 4.0 \\
\hline Overall mean & - & $7.40 \pm 0.08$ & - & - & - & - & \\
\hline
\end{tabular}

Mean \pm S.E. followed by small letters within column are significantly different ( $\leq \leq 0.05$; Tukey's HSD test)

Table 2

Hatching of S. inferens in different months during 2010-2011 and 2011-2012 crop season

\begin{tabular}{|c|c|c|c|c|c|c|c|c|c|}
\hline \multirow{2}{*}{ Years } & \multicolumn{8}{|c|}{ Hatching (\%) } & \multirow{2}{*}{$\begin{array}{l}\text { Overall } \\
\text { hatching } \\
(\%)\end{array}$} \\
\hline & $6 \mathrm{~d}$ & $7 \mathrm{~d}$ & $8 \mathrm{~d}$ & $9 \mathrm{~d}$ & $10 \mathrm{~d}$ & $11 \mathrm{~d}$ & $12 \mathrm{~d}$ & $13 \mathrm{~d}$ & \\
\hline $\begin{array}{l}2010- \\
2011\end{array}$ & $\begin{array}{c}20.03 \\
(26.55) \mathrm{a}\end{array}$ & $\begin{array}{l}41.65 \\
(40.14) \mathrm{a}\end{array}$ & $\begin{array}{c}13.79 \\
(21.68) \mathrm{a}\end{array}$ & $\begin{array}{c}6.39 \\
(14.57) a\end{array}$ & $\begin{array}{c}4.47 \\
(12.11) \mathrm{a}\end{array}$ & $\begin{array}{c}2.30 \\
(8.59) \mathrm{a}\end{array}$ & $\begin{array}{c}0.65 \\
(3.43) \mathrm{a}\end{array}$ & $\begin{array}{c}0.37 \\
(1.99) \mathrm{a}\end{array}$ & $\begin{array}{c}89.36 \\
(71.03) a\end{array}$ \\
\hline $\begin{array}{l}2011- \\
2012\end{array}$ & $\begin{array}{c}19.60 \\
(26.25) \mathrm{a}\end{array}$ & $\begin{array}{c}41.13 \\
(39.85) \mathrm{a}\end{array}$ & $\begin{array}{c}12.52 \\
(20.62) \mathrm{a}\end{array}$ & $\begin{array}{c}7.28 \\
(15.61) \mathrm{a}\end{array}$ & $\begin{array}{c}4.46 \\
(12.11) \mathrm{a}\end{array}$ & $\begin{array}{c}2.15 \\
(8.30) \mathrm{a}\end{array}$ & $\begin{array}{c}1.09 \\
(4.83) \mathrm{a}\end{array}$ & $\begin{array}{c}0.69 \\
(3.56) \mathrm{a}\end{array}$ & $\begin{array}{c}88.93 \\
(70.84) a\end{array}$ \\
\hline \multicolumn{10}{|c|}{ Months } \\
\hline $\begin{array}{l}\text { Oct- } \\
\text { Nov }\end{array}$ & $\begin{array}{c}21.28 \\
(27.45) \mathrm{a}\end{array}$ & $\begin{array}{c}44.75 \\
(41.96) \mathrm{a}\end{array}$ & $\begin{array}{c}10.62 \\
(18.96) a b\end{array}$ & $\begin{array}{c}7.27 \\
(15.56) \mathrm{a}\end{array}$ & $\begin{array}{c}3.77 \\
(11.10) \mathrm{a}\end{array}$ & $\begin{array}{c}1.75 \\
(7.51) \mathrm{a}\end{array}$ & $\begin{array}{c}0.00 \\
(0.00) \mathrm{b}\end{array}$ & $\begin{array}{c}0.00 \\
(0.00) \mathrm{b}\end{array}$ & $\begin{array}{c}88.89 \\
(70.54) a\end{array}$ \\
\hline $\begin{array}{l}\text { Nov- } \\
\text { Dec }\end{array}$ & $\begin{array}{c}19.74 \\
(26.35) \mathrm{a}\end{array}$ & $\begin{array}{c}42.77 \\
(40.81) a\end{array}$ & $\begin{array}{c}13.08 \\
(21.13) \mathrm{a}\end{array}$ & $\begin{array}{c}6.77 \\
(14.99) \mathrm{a}\end{array}$ & $\begin{array}{c}4.89 \\
(12.72) \mathrm{a}\end{array}$ & $\begin{array}{c}2.13 \\
(8.26) \mathrm{a}\end{array}$ & $\begin{array}{c}1.30 \\
(5.90) \mathrm{a}\end{array}$ & $\begin{array}{c}0.64 \\
(3.24) \mathrm{a}\end{array}$ & $\begin{array}{c}91.32 \\
(73.01) \mathrm{a}\end{array}$ \\
\hline $\begin{array}{l}\text { Dec- } \\
\text { Jan }\end{array}$ & $\begin{array}{l}18.42 \\
(25.39) \mathrm{ab}\end{array}$ & $\begin{array}{c}36.62 \\
(37.22) \mathrm{ab}\end{array}$ & $\begin{array}{c}15.76 \\
(23.35) \mathrm{a}\end{array}$ & $\begin{array}{c}6.48 \\
(14.72) \mathrm{a}\end{array}$ & $\begin{array}{c}4.72 \\
(12.52) \mathrm{a}\end{array}$ & $\begin{array}{c}2.79 \\
(9.57) \mathrm{a}\end{array}$ & $\begin{array}{c}1.30 \\
(6.49) a\end{array}$ & $\begin{array}{c}0.94 \\
(5.08) \mathrm{a}\end{array}$ & $\begin{array}{c}87.23 \\
(69.25) \mathrm{a}\end{array}$ \\
\hline
\end{tabular}

Mean followed by small letters within column are significantly different ( $\mathrm{p} \leq 0.05$; Tukey's HSD test); $d=d a y s$

October-November and 6-13 days during November-December and December-January. The decrease in photoperiod ( 4 hrs sunshine) coupled with low mean temperature $\left(11.5^{\circ} \mathrm{C}\right)$ and high humidity (79.2\%) might have resulted in higher incubation period during the months of December-January. An incubation period of 6-8 days was recorded in rice by Atwal and Chaudhry (1967) and Karim and Raizuddin (1999).

The hatching of eggs started 6 days after their laying and there was no difference $(\mathrm{p}>0.05 ; \mathrm{F}=0.07 ; \mathrm{df}=2,12)$ in overall per cent hatchability between 2010-2011 and 2011-2012 crop years (Table 2). Also there was no difference $(\mathrm{p}>0.05 ; \mathrm{F}=2.14 ; \mathrm{df}=2$, 12 ) in overall per cent egg hatchability among three months of study (October-November, 
November-December and December-January). Numerically, overall per cent hatchability of eggs was maximum during the month of November-December $(91.32 \%)$ followed by October-November (88.89\%) and December-January (87.23\%). Six and seven days after egg laying, per cent hatchability was significantly less in the months of December-January while 8, 12 and 13 days after egg laying, it was significantly less in October-November.

Site of oviposition:

The eggs were laid either at the base of plant near soil level or on soil surface or in the stubble of rice plants (Fig. 6). These were laid either singly or in clusters. Earlier studies indicated egg laying by $S$. inferens on the soil surface near the base of sugarcane (Rajendra, 1976) and rice plant (Agarwal and Siddiqui, 1964). Eggs were laid on the inner side of leaf sheath in basmati rice/maize (Aggarwal, 2002; Joshi et al., 2009; Sekhar et al., 2009).
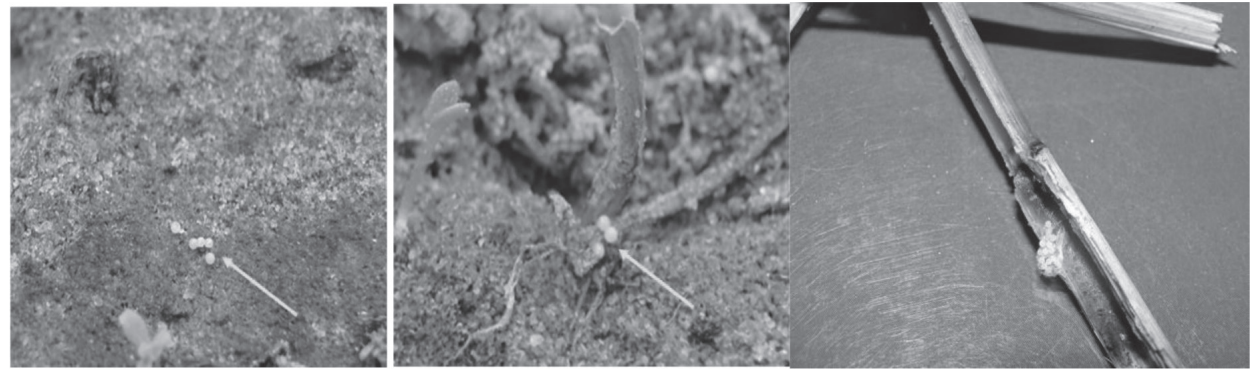

Fig. 6. Site of oviposition of Sesamia inferens

\section{Larval stage}

The larvae of $S$. inferens were smooth, uniformly pinkish-white in colour with dark brown to black head. Eight larval instars were observed in the present studies (Tables 3 and 4). Joshi et al. (2009) reported eight larval instars on Taraori basmati rice and Rothschild (1971) reported seven instars while Atwal and Chaudhry (1967); Cendana and Calora (1967) and Aggarwal (2002) recorded six instars on rice crop. The behaviour of different instars of $S$. inferens has been given in Table 5 and the appearance of $3^{\text {rd }}-8^{\text {th }}$ instar has been depicted in Fig. 7. The first and second instar larvae thrived on epidermal tissues of leaves and the third instar larvae were able to cause internal damage to wheat plants while others attacked 40- to 50-day-old plants. Fifth instar onwards larvae caused dead hearts. The eighth instar larva spun web around them and entered into pre-pupal stage.

Larval duration:

The mean larval duration of different instars was $4.31 \pm 0.11,4.37 \pm 0.14$, $4.67 \pm 0.19,5.78 \pm 0.19,7.14 \pm 0.24,15.98 \pm 0.30,16.52 \pm 0.25$ and $9.77 \pm 0.21$ days (Table 4). These findings corroborated the findings of Aggarwal (2002) with respect to duration of larval instars on rice crop. 


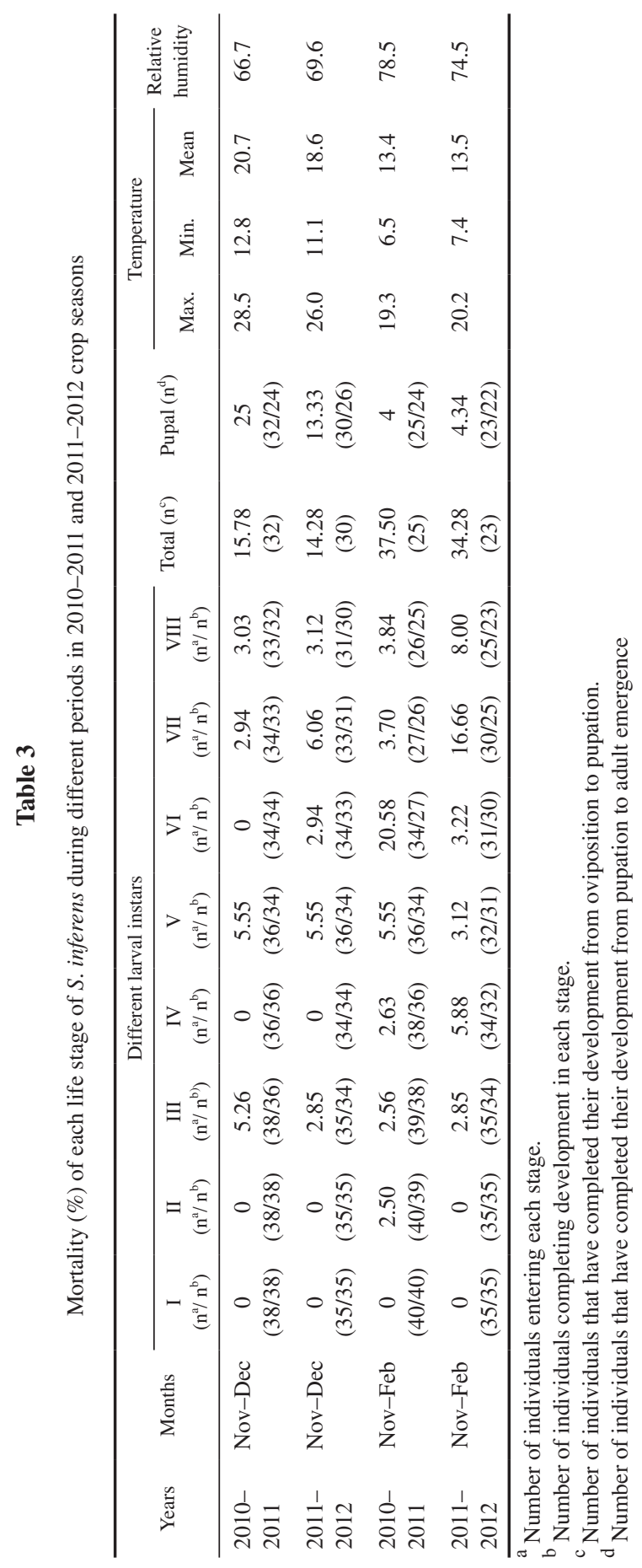

Acta Phytopathologica et Entomologica Hungarica 50, 2015 


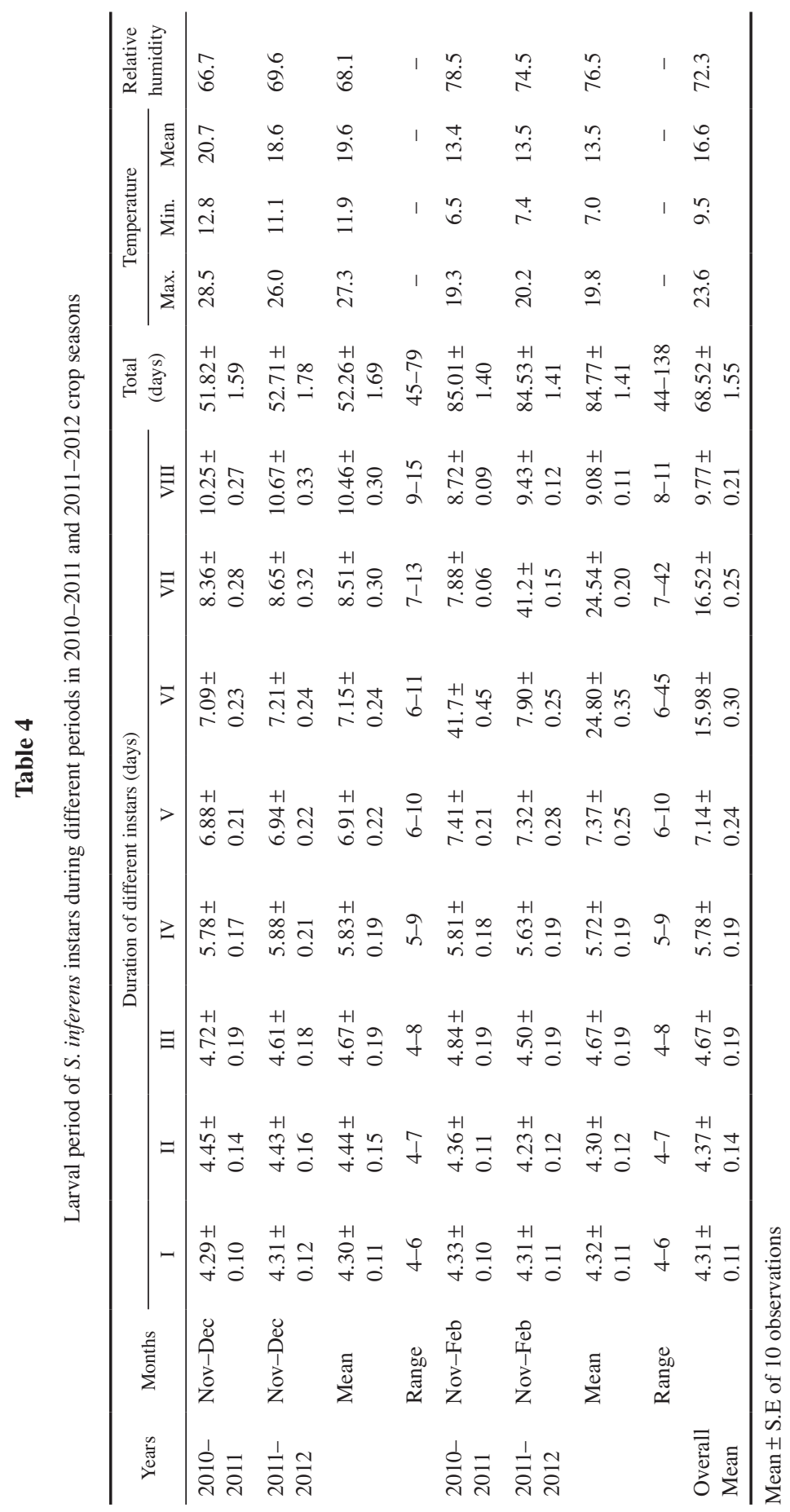


Table 5

Behaviour of different larval instars of S. inferens

\begin{tabular}{ll}
\hline Larval instars & Feeding behaviour \\
\hline I & Damaged epidermal tissues mainly when fed on leaves in plastic tube (straw) \\
II & Larvae destroyed 40 and 50 days old plant \\
III & Larvae were able to cause damage to wheat plants \\
III/IV & Larval feeding continued within stem and produced dead hearts \\
V/VI & Dead hearts were formed by larval feeding and larva also seen entering nearby tillers \\
VII and VIII instars & Feeding continued in new tillers; dead hearts formed and each tiller had 1-2 larvae in it \\
\hline
\end{tabular}

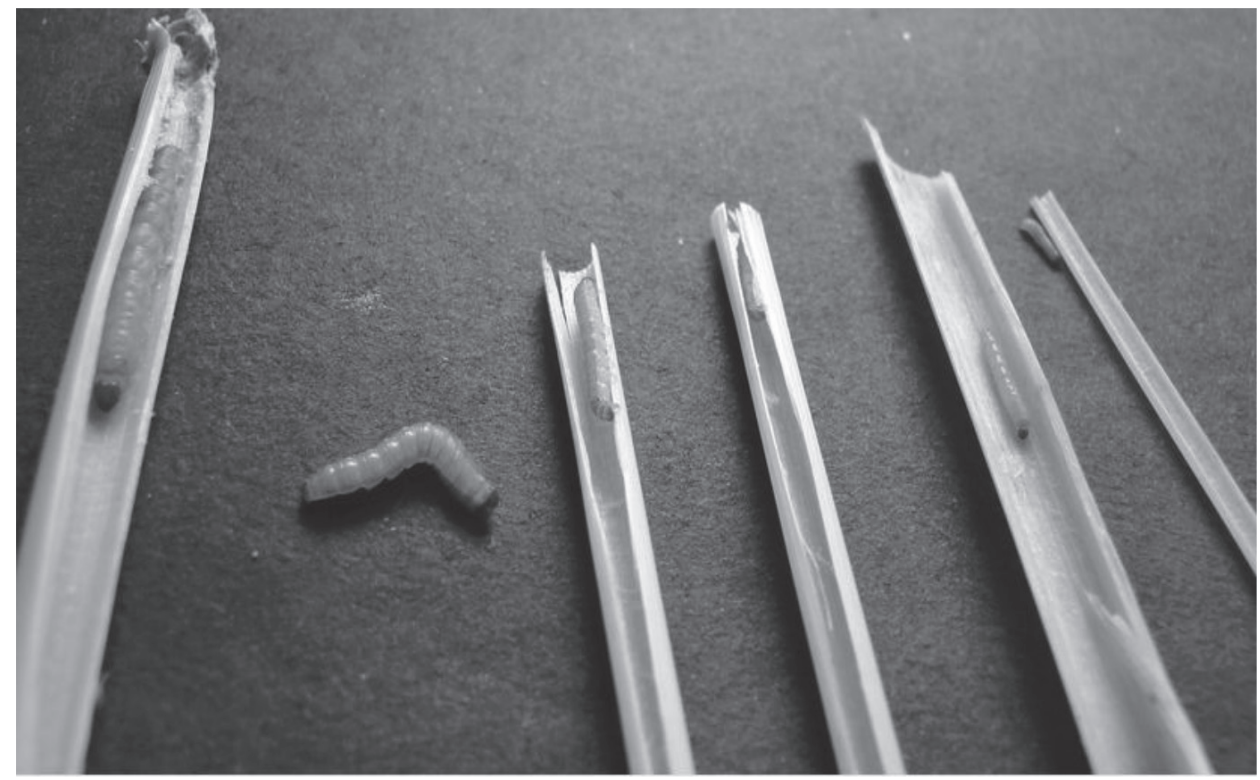

Fig. 7. Different larval instars of Sesamia inferens (3rd-8th instars)

There was no difference in I, II, III, IV, V instar duration between early November-December and late November-February while the duration of sixth (6-45 days) and seventh instar (7-42 days) got extended during later months. The total larval duration ranged from 45-79 days in November-December and 44-138 days in late NovemberFebruary. The present findings differ from Atwal and Chaudhry (1967) who reported $22.9 \pm 2.6$ days as the total larval duration in rice crop. Besides Aggarwal (2002) reported $30.86 \pm 0.50$ and $45.73 \pm 1.77$ days as the total larval duration in October-November and November-December, respectively in rice crop. Similarly, Rahman and Khalequzzaman (2004) also submitted $73.60 \pm 0.81$ and $56.55 \pm 0.92$ days as the larval duration of $S$. inferens at 15 and $20^{\circ} \mathrm{C}$ temperature, respectively. The present results on larval duration are 
in agreement with Joshi et al. (2009) who reported 67.44 \pm 0.55 days as total larval period in Taraori basmati rice.

No mortality was observed in I instar larvae during both the months of observations, i.e. early November-December and late November-February (Table 3). Also the survival of the first five instars was almost similar between two months of observations, however sixth instar (during 2010-2011) and seventh instar (during 2011-2012) experienced 20.58 and $16.66 \%$ mortality, respectively during the months of late November-February. At the same time pupal mortality was more in the months of late November-February during both the years.

A phase of inactive growth was also observed in sixth and seventh instar larva when the life cycle started from late November and larval period got extended up to early February. The larvae reared under short day conditions entered diapauses and passed through 12 larval instars before death/pupation (Hedo et al., 2012).

\section{Pupa stage}

The final instar larvae of S. inferens stopped feeding and spun a cocoon around them consisting of white silken thread and became inactive and started shrinking. With the passage of time, the colour of pupae changed to whitish brown to dark brown. The size of female pupae was comparatively larger than male and the genital aperture was present on ventral side $\left(9^{\text {th }}\right.$ sternite) in female while it was on $8^{\text {th }}$ sternite in case of males.

Pupal duration:

The total pupal period including pre-pupal period ranged from 47-52 days with a mean of $50.31 \pm 0.27$ days during December-February at a mean temperature of $12{ }^{\circ} \mathrm{C}$ and $78.8 \%$ R.H. (Table 6). It was 21-25 days with mean of $23.56 \pm 0.27$ days during February-March at a mean temperature of $16{ }^{\circ} \mathrm{C}$ and $73.5 \%$ R.H. The mean pupal duration of male was $49.08 \pm 0.50$ and $49.33 \pm 0.29$ days and female was $51.00 \pm 0.00$ and $51.33 \pm 0.26$ days in 2011 and 2012, respectively in December to February. The reduction in mean pupal period was observed in males (22.88 \pm 0.32 days $)$ and females $(24.39 \pm 0.21$ days) in February-March. The earlier findings indicated pupal period between 12-36 days in rice (Grist and Lever, 1969) and 9-11 days in sugarcane crop (Rajendra, 1976). The current finding on pupal duration during February and March are in line with those of Aggarwal (2002). Longer pupal duration obtained during the present studies is not in agreement with Atwal and Chaudhry (1967) and Rothschild (1971). It could be due to difference in temperature conditions prevailed during the study as pupal length is inversely proportional to temperature (Areekul and Chamchanya, 1973; Pathak and Khan, 1994; Rahman and Khalequzzaman, 2004).

\section{Site of pupation}

In field, pupae were observed in stubble of rice plant while in pots having rice stubble, 82.35 per cent pupation took place in rice stubble and 17.65 per cent on soil surface in 2010-2011 (Fig. 8). Similarly in 2011-2012, more than 80 per cent (80.95\%) larvae pupated in or near the base of stubble while only $19.05 \%$ larvae pupated on soil surface. 


\section{Adult stage}

The adult moths were fawn coloured, having light brown forewings and off-white hind wings. A large number of light brownish scales/hairs were present throughout the exposed surface of the body including wings. The colour of the head was dark brown. The antennae were pectinate in males and filiform in female which is an important character for the identification of sexes.

\section{Table 6}

Pupal duration of S. inferens in different months during 2010-2011 and 2011-2012

\begin{tabular}{|c|c|c|c|c|c|c|c|c|c|c|}
\hline \multirow{3}{*}{ Years } & \multirow{3}{*}{ Months } & \multicolumn{4}{|c|}{ Pupal duration (days) } & \multirow{3}{*}{ Mean } & \multicolumn{3}{|c|}{ Temperature } & \multirow{3}{*}{$\begin{array}{l}\text { Relative } \\
\text { humidity }\end{array}$} \\
\hline & & \multicolumn{2}{|c|}{ Males } & \multicolumn{2}{|c|}{ Females } & & & & & \\
\hline & & Range & Mean & Range & Mean & & & & & \\
\hline $\begin{array}{l}2010- \\
2011\end{array}$ & $\begin{array}{l}\text { December- } \\
\text { February }\end{array}$ & $47-51$ & $\begin{array}{l}49.08 \pm \\
0.50\end{array}$ & $47-51$ & $\begin{array}{c}51.00 \pm \\
0.00\end{array}$ & $\begin{array}{l}50.04 \pm \\
0.25\end{array}$ & 17.2 & 5.5 & 12.3 & 81.0 \\
\hline $\begin{array}{l}2011- \\
2012\end{array}$ & $\begin{array}{l}\text { December- } \\
\text { February }\end{array}$ & $50-52$ & $\begin{array}{l}49.33 \pm \\
0.29\end{array}$ & $50-52$ & $\begin{array}{c}51.33 \pm \\
0.26\end{array}$ & $\begin{array}{l}50.58 \pm \\
0.28\end{array}$ & 18.2 & 6.5 & 11.7 & 76.6 \\
\hline Mean & - & - & $\begin{array}{l}49.21 \pm \\
0.40\end{array}$ & - & $\begin{array}{c}51.17 \pm \\
0.13\end{array}$ & $\begin{array}{l}50.31 \pm \\
0.27\end{array}$ & 17.7 & 6.0 & 12.0 & 78.8 \\
\hline $\begin{array}{l}2010- \\
2011\end{array}$ & $\begin{array}{l}\text { February- } \\
\text { March }\end{array}$ & $21-24$ & $\begin{array}{l}21.92 \pm \\
0.35\end{array}$ & $21-24$ & $\begin{array}{c}23.67 \pm \\
0.12\end{array}$ & $\begin{array}{l}22.79 \pm \\
0.24\end{array}$ & 23.9 & 10.8 & 17.4 & 78.3 \\
\hline $\begin{array}{l}2011- \\
2012\end{array}$ & $\begin{array}{l}\text { February- } \\
\text { March }\end{array}$ & $23-25$ & $\begin{array}{l}23.83 \pm \\
0.28\end{array}$ & $23-25$ & $\begin{array}{c}25.10 \pm \\
0.29\end{array}$ & $\begin{array}{l}24.32 \pm \\
0.29\end{array}$ & 21.6 & 7.7 & 14.7 & 68.7 \\
\hline Mean & - & - & $\begin{array}{l}22.88 \pm \\
0.32\end{array}$ & - & $\begin{array}{c}24.39 \pm \\
0.21\end{array}$ & $\begin{array}{l}23.56 \pm \\
0.27\end{array}$ & 22.7 & 9.2 & 16.0 & 73.5 \\
\hline $\begin{array}{l}\text { Overall } \\
\text { Mean }\end{array}$ & & - & $\begin{array}{l}36.05 \pm \\
0.36\end{array}$ & - & $\begin{array}{c}37.78 \pm \\
0.17\end{array}$ & $\begin{array}{l}36.94 \pm \\
0.27\end{array}$ & 20.2 & 7.6 & 14.0 & 76.2 \\
\hline
\end{tabular}

Mean \pm S.E. of 10 observations
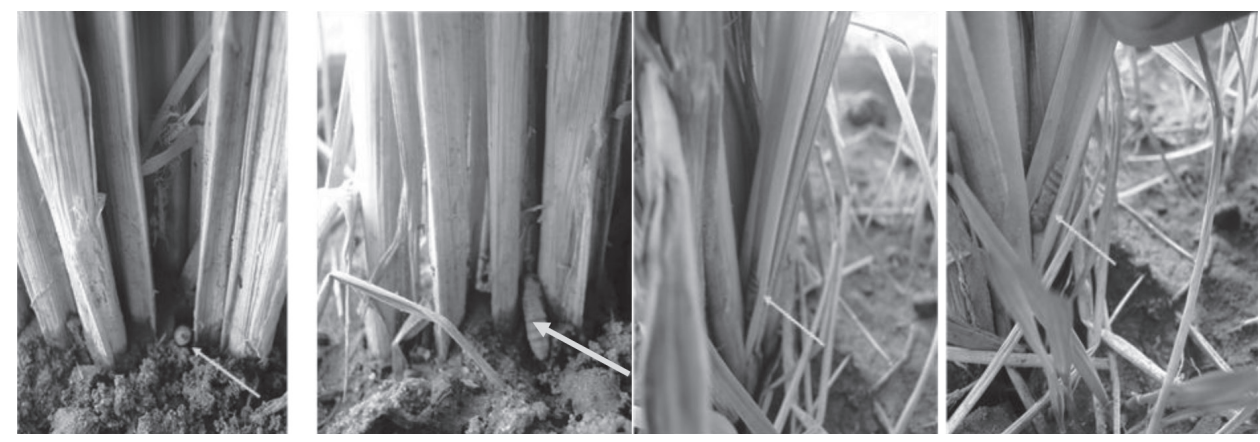

Fig. 8. Place of pupation of Sesamia inferens (on the soil surface and within the stubble of rice plant) 


\section{Adult longevity and ovipositional periods}

Ovipositional periods:

The pre-oviposition period of females in the month of February $(1.82 \pm 0.11$ days $)$ was significantly higher $(\mathrm{p}<0.05 ; \mathrm{F}=3.40 ; \mathrm{df}=2,27)$ than October $(1.53 \pm 0.09$ days $)$ which was on a par with November (1.65 \pm 0.08 days) during 2010-2011 (Table 7). It was very difficult to differentiate oviposition and post-oviposition period as the females of $S$. inferens continued egg laying even on the last day of their life. Thus, oviposition and post-oviposition period were clubbed together and it ranged from 3.00-6.75 days with a mean of $4.94 \pm 0.25$ days in 2010-2011. This period was significantly higher $(\mathrm{p}<0.05$; $\mathrm{F}=6.55 ; \mathrm{df}=2,27)$ in the month of February (5.54 \pm 0.29 days) than October $(4.40 \pm 0.28$ days) which was on a par with November (4.88 \pm 0.16 days) during 2010-2011.

Adult longevity:

The longevity of males ranged between 4.00-7.00 days with a mean of $5.31 \pm 0.26$ days during 2010-2011 (Table 8). However, the females lived slightly longer with a mean of $6.61 \pm 0.26$ days during 2010-2011. The longevity of ( $7.36 \pm 0.39$ days female; $6.14 \pm 0.22$ days males) was significantly higher (females: $\mathrm{p}<0.05 ; \mathrm{F}=10.14 ; \mathrm{df}=2,27$;

\section{Table 7}

Pre-oviposition and oviposition periods of adults of S. inferens during 2010-2011

\begin{tabular}{lccccccccc}
\hline \multirow{2}{*}{ Years } & \multirow{2}{*}{ Month } & \multicolumn{2}{c}{ Pre-oviposition period (days) } & \multicolumn{2}{c}{ Oviposition period (days) } & \multicolumn{3}{c}{ Temperature } & \multicolumn{2}{c}{ Relative } \\
& & Mean \pm S.E. & Range & Mean \pm S.E. & Range & Max. & Min. & Mean & humidity \\
\hline $\begin{array}{l}2010- \\
2011\end{array}$ & Oct 2010 & $1.53 \pm 0.09 \mathrm{~b}$ & $1.25-2.00$ & $4.40 \pm 0.28 \mathrm{~b}$ & $3.00-5.75$ & 31.9 & 19.4 & 25.6 & 71.5 \\
& Nov 2010 & $1.65 \pm 0.08 \mathrm{ab}$ & $1.25-2.00$ & $4.88 \pm 0.16 \mathrm{ab}$ & $4.00-5.50$ & 27.0 & 11.3 & 19.2 & 67.0 \\
& Feb 2011 & $1.82 \pm 0.11 \mathrm{a}$ & $1.50-2.25$ & $5.54 \pm 0.29 \mathrm{a}$ & $4.50-6.75$ & 21.2 & 9.1 & 15.2 & 81.0 \\
& Mean & $1.67 \pm 0.09$ & $1.25-2.25$ & $4.94 \pm 0.25$ & $3.00-6.75$ & 26.7 & 13.27 & 20.0 & 73.2 \\
\hline
\end{tabular}

Mean \pm S.E. followed by small letters within column are significantly different ( $\mathrm{p} \leq 0.05$; Tukey's HSD test)

Table 8

Adult longevity of S. inferens in different months during 2010-2011

\begin{tabular}{|c|c|c|c|c|c|c|c|c|c|}
\hline \multirow{2}{*}{ Years } & \multirow{2}{*}{ Month } & \multicolumn{2}{|c|}{ Female } & \multicolumn{2}{|c|}{ Male } & \multicolumn{3}{|c|}{ Temperature } & \multirow{2}{*}{$\begin{array}{l}\text { Relative } \\
\text { humidity }\end{array}$} \\
\hline & & Mean & Range & Mean & Range & Max. & Min. & Mean & \\
\hline \multirow[t]{4}{*}{$\begin{array}{l}2010- \\
2011\end{array}$} & Oct 2010 & $5.93 \pm 0.23 b$ & $\begin{array}{l}5.00- \\
7.00\end{array}$ & $4.70 \pm 0.14 b$ & $\begin{array}{l}4.00- \\
5.25\end{array}$ & 31.9 & 19.4 & 25.6 & 71.5 \\
\hline & Nov 2010 & $6.53 \pm 0.17 b$ & $\begin{array}{l}5.75- \\
7.50\end{array}$ & $5.08 \pm 0.16 b$ & $\begin{array}{l}4.25- \\
5.75\end{array}$ & 27.0 & 11.3 & 19.2 & 67.0 \\
\hline & Feb 2011 & $7.36 \pm 0.39 a$ & $\begin{array}{l}6.00- \\
9.00\end{array}$ & $6.14 \pm 0.22 \mathrm{a}$ & $\begin{array}{l}5.25- \\
7.00\end{array}$ & 21.2 & 9.1 & 15.2 & 81.0 \\
\hline & Mean & $6.61 \pm 0.26$ & - & $5.31 \pm 0.26$ & - & 26.7 & 13.3 & 20.0 & 73.2 \\
\hline
\end{tabular}

Mean \pm S.E. followed by small letters within column are significantly different ( $\mathrm{p} \leq 0.05$; Tukey’s HSD test) 
males: $\mathrm{p}<0.05 ; \mathrm{F}=24.82 ; \mathrm{df}=2,27)$ in February 2011 as compared to October 2010 (5.93 \pm 0.23 females; $4.70 \pm 0.14$ males) and November 2010 (6.53 \pm 0.17 females; $5.08 \pm 0.16$ males). The present findings are in accordance with Rajendra (1976); Lu and Tan (1981) and Aggarwal (2002) who reported 5-7, 4.55-6.50 and 4-5 days adult longevity in sugarcane and rice crops, respectively. However, the present results differ from the studies of Joshi et al. (2009) who reported a relatively longer period of adult longevity $(10.90 \pm 0.48$ to $11.40 \pm 0.75$ days) in Taraori basmati rice.

\section{Sex ratio}

The sex ratio (males: females) was 1:1 (February 2011) and 1:1.08 (March 2011), respectively. The sex ratio of 1:0.86 and 1:0.83 was observed during February and March 2012, respectively. The overall mean sex ratio was 1: 0.94 which indicated that approximately equal numbers of males and females emerged during both years. The present observations are in agreement with those reported by Atwal and Chaudhry (1967) and Aggarwal (2002).

\section{Fecundity and hatchability}

There was no difference $(\mathrm{p}>0.05 ; \mathrm{F}=0.04 ; \mathrm{df}=1,54)$ in fecundity during 2010-2011 (117 \pm 11.79$)$ and 2011-2012 (119.37 \pm 12.05$)$ (Table 9). However, it was significantly more $(\mathrm{p}<0.05 ; \mathrm{F}=7.59 ; \mathrm{df}=2,54)$ in the months of October-November $(140.35 \pm 12.14)$ as compared to November-December (120.65 \pm 12.33$)$ which was on a par with December-January $(94.00 \pm 11.25)$. The fecundity of females of $S$. inferens varied from 77-212, 68-198 and 51-179 eggs in the months of October-November, November-December and December-January, respectively. These studies were substantiated by the findings of Allsopp and Sallam (2001) and Aggarwal (2002) who reported 300 and 76-271 as fecundity of females of S. inferens, respectively, in the month of November. The average fecundity and hatchability of $S$. inferens were 332.1 and $87.04 \pm 3.18$ per

\section{Table 9}

Fecundity of S. inferens during different periods in 2010-2011 and 2011-2012

\begin{tabular}{|c|c|c|c|c|c|c|}
\hline \multirow{2}{*}{ Years } & \multicolumn{2}{|c|}{ Fecundity } & \multicolumn{3}{|c|}{ Temperature } & \multirow{2}{*}{$\begin{array}{l}\text { Relative } \\
\text { humidity }\end{array}$} \\
\hline & Range & Mean \pm S.E. & Max. & Min. & Mean & \\
\hline 2010-2011 & $51-212$ & $117.39 \pm 11.79 \mathrm{a}$ & 26.7 & 13.3 & 20.0 & 73.2 \\
\hline 2011-2012 & $56-210$ & $119.37 \pm 12.05 \mathrm{a}$ & 27.1 & 13.0 & 19.7 & 69.4 \\
\hline \multicolumn{7}{|l|}{ Months } \\
\hline Oct - Nov & $77-212$ & $140.35 \pm 12.14 \mathrm{a}$ & 32.1 & 18.7 & 25.3 & 69.0 \\
\hline Nov-Dec & $68-198$ & $120.65 \pm 12.33 \mathrm{a}$ & 27.3 & 11.9 & 19.7 & 68.0 \\
\hline Dec-Jan & $51-179$ & $94.00 \pm 11.25 b$ & 21.4 & 8.8 & 14.6 & 76.9 \\
\hline Mean & - & $118.33 \pm 11.93$ & & & & \\
\hline
\end{tabular}

Mean \pm S.E. followed by small letters within column are significantly different ( $\mathrm{p} \leq 0.05$; Tukey's HSD test) 


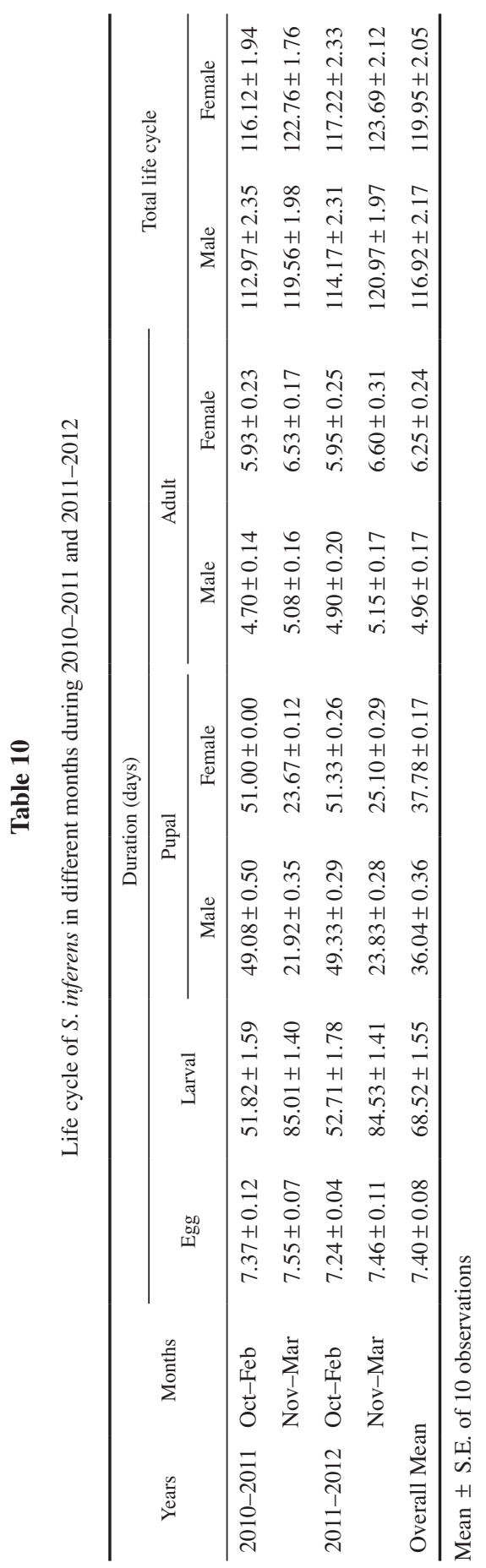


cent, respectively in Taraori Basmati rice (Joshi et al., 2009). Rajendra (1976) reported $150-400$ eggs as the fecundity of $S$. inferens in sugarcane crop. The females of S. calamistis laid about 300 eggs in her entire life cycle (Shanower et al., 1983).

\section{Total life cycle}

The total life cycle of males and females of $S$. inferens from egg laying to adult emergence was completed in $112.97 \pm 2.35$ and $116.12 \pm 1.94$ days, respectively when the life cycle extended from the last week of October to the second week of February 2010-2011 (Table 10). However, the duration of total life cycle was $114.17 \pm 2.31$ and $117.22 \pm 2.33$ days for males and females, respectively, in the same months during 20112012. A slightly prolonged life cycle was observed during the second fortnight of November to the first fortnight of March. It was $119.56 \pm 1.98$ and $122.76 \pm 1.76$ days in 2010-2011 and 120.97 \pm 1.97 and 123.69 \pm 2.12 days during 2011-2012 for males and females, respectively.

The present studies revealed that the life of $S$. inferens got extended during winter season. This has also been reported by Krishnamurti and Usman (1952) in ragi crop (Eleusine coracana [Eleusine indica]) in Mysore. The total duration of the life cycle of $S$. inferens averaged 45.6 days in summer and 71.1 days in winter. Shorter life cycle of 34-44 days was reported by Atwal and Chaudhry (1967) in summers in rice crop. Similarly, the life cycle of S. inferens ranged 38-68 days in the Philippines (Cendana and Calora, 1967), 45-90 days in Malaysia (Litsinger, 1977) during different months in rice crop. Rajendra (1976) reported that $S$. inferens lived for 65-84 days during different months on sugarcane crop. The total life cycle $S$. grisescens has been reported as 60-70 days (Allsopp and Sallam, 2001). The studies of Joshi et al. (2009) on Taraori Basmati rice are in total agreement with present findings which explained that the $S$. inferens completed its post embryonic development in 78.76 days in males and 82.50 days in females.

\section{Literature}

Adler, P. H., Willey, M. B. and Bowen, M. R. (1991): Temporal oviposition patterns of Heliothis zea and Spodoptera ornithogalli. Entomologia Experimentalis et Applicata 58, 159-164.

Aggarwal, R. (2002): Studies on the biology of pink stem borer, Sesamia inferens Walker on rice-crop. M. Sc. Thesis, Punjab Agricultural University, Ludhiana.

Agarwal, R. A. and Siddiqui, Z. A. (1964): Sugarcane pests. Indian J. Entomol. 25, 155-159.

Allsopp, P. G. and Sallam, M. S. (2001): BSS249 Preparedness for borer incursion Sesamia incursion management plan Version I, BSES Project report. Bureau of Sugarcane Experiment Station, Queensland, Australia, pp. 1-95.

Anonymous (2008): Wheat Crop Health Newsletter. Directorate of Wheat Research, Karnal. 14: p.1. (available at www.dwr.in).

Anonymous (2010): Package of Practices for Crops of Punjab. Rabi. Punjab Agricultural University, Ludhiana, pp. 1-17.

Areekul, S. and Chamchanya, T. (1973): Effect of humidity, temperature and light on the growth and development of Sesamia inferens Walker. Kasetsart 7, 65-75.

Atwal, A. S. and Chaudhry, J. P. (1967): Studies on the insect pests of rice. Annual Report of 1966-67. Department of Zoology-Entomology, Punjab Agricultural University, Ludhiana, pp. 55-77. 
Calatayud, P. A., Guenego, H., Le, R. B., Silvain, J. F. and Frerot, B. (2007): Temporal patterns of emergence, calling behaviour and oviposition period of the maize stem borer, Busseola fusca (Fuller) (Lepidoptera: Noctuidae). Annal. Soc. Ent. France, 43, 63-68.

Cendana, S. M. and Calora, F. B. (1967): Insect pest of rice in the Philippines. Proceeding of International Symposium. International Rice Research Institute, Philippines, pp. 591-616.

Dale, D. (1994): Insect pests of rice plant their biology and ecology. In: E. A. Heinrich (ed.): Biology and Management of Rice Insects. Wiley Eastern Limited, IRRI, pp. 364-486.

Deol, G. S. (2002): Latest trends for insect-pest management in wheat. Paper presented in specialized workshop on "Identification and management of weeds, insect pests and diseases in wheat", held at CETWPT, P.A.U., Ludhiana.

Dhaliwal, G. S., Jindal, V. and Dhawan, A. K. (2010): Insect pest problems and crop losses: Changing trends. Indian J. Ecology 37, 1-7.

Eizaguirre, M., López, C., Asin, L. and Albajes, R. (1994): Thermoperiodism, photoperiodism and sensitive stage in the diapause induction of Sesamia nonagrioides (Lepidoptera: Noctuidae). J. Insect Physiol. 40, $113-119$

Fantinou, A. A., Karandinos, M. G. and Tsitsipis, J. A. (1995): Diapause induction in the Sesamia nonagrioides (Lepidoptera: Noctuidae) effect of photoperiod and temperature. Environ. Entomol. 24, 1458-1466.

Fantinou, A. A., Perdikis, D. C. and Zota, K. (2004): Reproductive responses to photoperiod and temperature by diapausing and non-diapausing populations of Sesamia nonagrioides Lef. (Lepidoptera-Noctuidae). Physiol. Entomol. 29, 169-175.

Gomez, K. A. and Gomez, A. A. (1984): Statistical Procedures in Agricultural Research. Wiley, 2nd edition, New York, Chichester, etc.: pp. 1-680.

Grist, D. H. and Lever, R. J. (1969): Pests of Rice. Longmans, Green and Co Ltd, London and Harlow, pp. 117-226.

Hedo, M. P., Lopez, I. S. and Eizaguirre, M. (2012): Comparative analysis of hemolymph proteome maps in diapausing and non-diapausing larvae of Sesamia nonagrioides. Proteome Science 10, 58. (doi: 10.1186/1477-5956-10-58).

Huang, S. H., Cheng, C. H. and Yang, H. Y. (2008): Investigation on the occurrence of rice stem borers in central Taiwan. Plant Protection Bulletin 50, 37-46. (in Chinese)

Joshi, G., Ram, L. and Singh, R. (2009): Biology of pink borer, Sesamia inferens Walker on Taraori Basmati rice. Annals of Biology (Hisar) 25, 41-45.

Karim, S. and Raizuddin, S. (1999): Rice insect pests of Pakistan and their control: A lesson from past for sustainable future integrated pest management. Pakistan J. Biol. Sci. 2, 261-76.

Khan, Z. R., Litsinger, J. A., Barrion, A. T., Villanueva, F. F. D., Fernandez, N. J. and Taylor, L. D. (1991): World Bibliography of Rice Stem Borers. International Rice Research Institute, Los Banos, Philippines, pp. 1-176.

Krishnamurti, B. and Usman, S. (1952): The ragi stem borer Sesamia inferens Walker. Bulletin Department of Agriculture Mysore (Ent Ser) 15, 1-70.

Lina, X., Changchun, L., Benjin, H., Ziyan, Z., Xiaoxia, L., Shourong, L. and Wenjin, L. (2012): Preliminary investigation on damage of PSB on wheat. CNKI Plant Protection 2. (www. http://en.cnki.com.cn/Article_en/CJFDTotal-ZWBH201202044.htm)

Lisa, C. M., Amani, E. E. O. and Jensen, H. H. (2000): The geography and causes of food insecurity in developing countries. Agriculture Economics 22, 199-215.

Litsinger, J. A. (1977): Pests in tropical crops. In: J. Kranz, H. Schmutterer and W. Koch (eds): Diseases, Pests and Weeds in Tropical Crops. Verlag Paul Parey, Berlin and Hamburg, Germany, pp. 453-498.

Liu, T. S. (1990): A survey on the occurrence of rice stem borers and their damage in Taichung Areas. Bulletin Taichung DAIS 29, 39-47. (in Chinese)

Lu, Z. X. and Tan, L. S. (1981): Preliminary observations on the bionomics of Sesamia inferens Walker. Insect Knowledge 18, 151-154.

Patel, R. K. and Verma, R. (1980): Sex dimorphism in pink stem borer, Sesamia inferens Walker (Lepidoptera: Noctuidae). Science and Culture 46, 95-96. 
Pathak, M. D. (1975): Insect Pests of Rice. International Rice Research Institute, Los Banos, Philippines, pp. $1-15$.

Pathak, M. D. and Khan, Z. R. (1994): Insect Pests of Rice. International Rice Research Institute, Los Banos, Philippines, pp. 5-17.

Rahman, M. T. and Khalequzzaman, M. (2004): Temperature requirements for the development and survival of rice stem borers in laboratory conditions. Acta Entomol. Sinica 11, 47-60.

Rajendra, A. (1976): Studies on Sesamia inferens WIk. The shoot borer pest of sugarcane in Sri Lanka.1. Life cycle and aspects of biology. J. National Sci. Council Sri Lanka 4, 99-108.

Ram, H., Singh, B., Sharma, I., Bimbraw, A. S. and Mavi, G. S. (2011): Potentials of resource conservation technology and incidence of pink stem borer (Sesamia inferens) in various varieties of wheat (Tritcum aestivum L.). Proceeding of $3^{\text {rd }}$ International Group Meeting on "Wheat Productivity Enhancement under Changing Climate" February 9-12, 2011, held at UAS, Dharwad, India, 149 p.

Rothschild, G. H. L. (1971): The biology and ecology of rice stem borers in Sarawak (Malaysian Borneo). J. Applied Ecol. 8, 287-322.

Sekhar, J. C., Kumar, P., Rakshit, S., Singh, K. P. and Dass, S. (2009): Differential preference for oviposition by Sesamia inferens Walker on maize genotypes. Annals of Plant Protection Science 17, 46-49.

Severin, H. H. P. (1931): Modes of antilops transmission by beet leaf bettle Eutettix tenellus (Baker). Hilgardia 6, 254-256.

Shanower, T. G., Schulthess, F. and Bosque-Perez, N. A. (1983): Development and fecundity of Sesamia calamistis (Lepidoptera: Noctuidae) and Eldana saccharina (Lepidoptera: Pyralidae). Bulletin Entomol. Res. 83, 237-243.

Singh, V. S. (1986): Management of insect and mite pests. In: J. P. Tandon and A. P. Sethi (eds): Twenty Years of Coordinated Wheat Research 1961-86. Wheat Project Directorate, All India Coordinated Wheat Improvement Project, ICAR, India, pp. 158-188.

Singh, B. and Kular, J. S. (2012): Incidence and management of pink stem borer (Sesamia inferens) in ricewheat cropping system. J. Insect Sci. (Special issue): 142-145.

Trostle, R. and Seeley, R. (2013): Developing countries dominate world demand for agricultural products. Rada USDA, Economic Research Service. Available online at www. Ers.usda.gov/amber-wave/2013 (accessed 6 January, 2014). 